where contemporaneous planktonic-foraminiferal pelagites accumulated. Middle Eocene to middle Miocene carbonate rocks deposited in the deep-sea realm represent a distinctive lithogenetic unit herein united as the Montpelier Group.

The preponderance of globigerinid and radiolarian tests typifies lower Montpelier (late Eocene to early Miocene) microfossil assemblages. Dominant benthic forms include Melonis pompilioides, Fontbontia wuellorstorfi, and species of Stilostomella and Pleurostomella. Available faunal criteria including assemblage parameters, depth preferences for extant species, and convergent-ecologic morphologies suggest that abyssal (below $2,000 \mathrm{~m}$ ) paleodepths prevailed at the depositional site on a sediment apron at the base of the Duanvale-Wagwater escarpment. Middle Eocene to early Miocene subsidence computed from inferred paleodepth and estimated sedimentary thickness totals $2,800 \mathrm{~m}$. Biostratigraphic and paleoecologic evidence does not support the concept of a regional unconformity within the Montpelier, as has been proposed.

STEININGER, FRITZ F., Dept. Geol. Sci., Univ. Southern California, Los Angeles, Calif.

\section{NEOGENE STRATIGRAPHY OF PARATETHYS OF CEN- TRAL EUROPE AND ITS CORRELATION WITH OTHER AREAS}

During the last 10 years, a group of Neogene specialists has restudied the Neogene sections in the Alpine and Carpathian foredeep (molasse zone) and the inner Alpine and Carpathian basins. These studies have given rise to a new Neogene stratigraphic concept for this area-the so-called "Paratethys."

The lower boundaries of these Miocene and Pliocene stages (Egerian, Eggenburgian, Ottnangian, Carpathian, Badenian, Sarmatian, Pannonian, Pontian, Dacian, and Romanian, in ascending order) are defined by planktonic and larger foraminifers, calcareous nannoplankton, ostracods, mollusks, microvertebrates, and macrovertebrates. From radiometric age determinations of biostratigraphically dated glauconite and rhyolitic or andesitic tuff zones, correlations are possible with the Neogene planktonic zonation of Blow on one side, and with vertebrate Neogene scales on the other. Correlations can be made between the boreal, Atlantic, and Mediterranean bioprovinces of Europe and, therefore, with most of the stratotypes of the international Neogene time scale. On the basis of Paratethys faunas, the bioprovinces of western Europe can be correlated with the eastern Neogene deposits as far as the Crimean and Caspian Sea areas. Planktonic and larger foraminifers, as well as microvertebrates and macrovertebrate correlation levels, can be related to the Neogene of the United States. There are major conflicts between the early and middle Miocene radiometric dates obtained in the Paratethys and those from deep-sea cores.

STEVENS, CaLviN H., Dept. Geology, California State Univ., San Jose, Calif.

MAJOR PERMIAN TECTONIC FEATURES AND POSTPERMIAN DISPLACEMENTS IN WESTERN UTAH, NEVADA, AND SOUTHEASTERN CALIFORNIA, AS REFLECTED BY DISTRIBUTION OF PERMIAN RIEPE SPRING CORALLINE FACIES

Several facies of the Riepe Spring Limestone and its equivalents in Utah, Nevada, and California have been recognized. The most distinctive is limestone with massive, rugose corals. This facies is interpreted as representing low-energy, shallowshelf deposition, on the basis of sedimentary characteristics and abundance of algae. Generally eastward, the coralline facies is replaced by dolomite and sandstone representing nearshore, restricted environments of deposition. Westward, higher energy and/or deeper water deposits accumulated. The coralline facies forms a band $15-50 \mathrm{mi}$ wide that extends from southern Idaho to southeastern California. In northeastern Nevada and western Utah, this facies forms an enormous westward-directed loop, where it accumulated around an approximately westwardtrending axis of restricted environments. In southern Nevada and southeastern California, the coralline facies clearly is offset tens of miles in a right-lateral sense on the Las Vegas shear zone and on the Furnace Creek-Death Valley fault zones. Southeast of the Garlock fault, either facies trends shift directions abruptly, or there has been tens of miles of movement in a left-lateral sense.

STEWART, J. H., and F. G. POOLE, U.S. Geol. Survey, Menlo Park, Calif.

UPPER PRECAMBRIAN AND LOWER PALEOZOIC MIOGEOCLINE IN GREAT BASIN, WESTERN UNITED STATES

Shallow-marine, intertidal, and supratidal detrital and carbonate strata of late Precambrian (less than $850 \mathrm{~m} . \mathrm{y}$.) and early Paleozoic (more than 345 m.y.) age thicken from a few thousand feet in cratonic areas east of the Great Basin to $40,000 \mathrm{ft}$ in the central Great Basin 200-300 mi west. Coeval rocks in the western Great Basin are deep-water strata characterized by chert and argillite associated with mafic pillow lavas. Strata deposited at moderate depths are present between the shallowand deep-water facies, but have a limited distribution, suggesting a relatively abrupt transition from shelf to deep-ocean basin. The thick accumulation of shallow-water deposits in the Great Basin is similar to deposits along present-day stable continental margins. Such accumulations have been termed miogeoclines, rather that miogeosynclines, because they are open to the sea on one side and are not synclinal in form.

The continental margin along which the late Precambrian and early Paleozoic miogeocline was constructed apparently developed as the result of a late Precambrian (less than 850 m.y.) continental separation. Extensional faulting and flowage related to this separation extended well into the continent and may have produced major crustal thinning as far east as the "Wasatch line," across which the rate of westward thickening of upper Precambrian and Paleozoic strata increases markedly. A persistent positive belt, perhaps analogous to the buried ridge beneath the outer edge of the present-day Atlantic continental shelf, may account for regional thinning and local erosional truncation of lower Paleozoic strata along the western margin of the Cordilleran miogeocline.

STRIDE, ARTHUR H., National Inst. Oceanography, Wormley, Godalming, Surrey, England

\section{MODELS FROM EUROPEAN SEAS TO AID DETECTION} OF, AND SEARCH FOR, ANCIENT SAND BODIES

Many large porous sand bodies formed in open reaches of ancient continental shelves and slopes should be recognizable in the stratigraphic record; they have considerable economic and academic significance. The present paper is concerned with modern analogues in the shallow seas around western Europe. The new deposits and their depositional environment allow the depositional environment of the ancient ones to be interpreted more realistically. In addition to the extensive but thin sand sheets, there are many modern sand bodies that are isolated from one another. They can be tens of miles in length, a few miles wide, and more than $200 \mathrm{ft}$ thick. They may occur singly or in extensive groups and are parallel with or transverse to the currents that formed them. Some of the largest ones were made by the Mediterranean undercurrent on the continental slope of the Gulf of Cadiz. Others, of similar size on the continental shelf, are attributed to a tidal-current origin. Modern tidal flow around the British Isles also is responsible for such sand bodies, as well as a variety of other forms. Only semiunidirectional currents seem to be depositing sand in the western approaches to the Baltic.

SUPKO, PETER R., Scripps Institution of Oceanography, La Jolla, Calif., PETER STOFFERS, Mineralogisches Institut, 